\title{
The Female Visitor and the Marriage of Classes in Gaskell's North and
}

South

\author{
DORICE WILLIAMS ELLIOTT
}

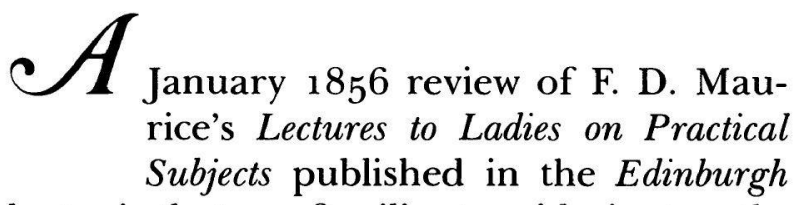

Review addressed a topic that was familiar to mid-nineteenthcentury audiences:

It is plain that this whole matter of visiting among the poor, whether isolated or organised visiting be in question, is the subject of much anxiety to many of the lecturers. . . It is no wonder it should be so. All see how dangerous a thing it would be to check these intercourses; often the sole means by which the rich obtain an insight into the struggles of the poor. Yet we are constantly made aware of other dangers arising out of visiting; and especially of District Visiting. ${ }^{1}$

The reviewer's language calls attention to the uneasiness that many people in mid-nineteenth-century England felt on the subject of female visitors to the poor. The position of the female visitor, as the reviewer presents it, is one of double danger: it would be "dangerous" to "check" their dealings with the poor, but those very dealings are fraught with "other

(C) 1994 by The Regents of the University of California

1 Review of Lectures to Ladies on Practical Subjects, Edinburgh Revıew, 103 (1856), 146-53; rpt. in Elizabeth Gaskell: The Critical Heritage, ed. Angus Easson (New York: Routledge, 1991 ), p. 369 . 
friendships with working men. ${ }^{11}$ But the most frequent and common interpersonal exchanges between members of different classes were those between middle-class women and their servants and between female visitors and the poor families they visited. ${ }^{12}$ Thus, such contacts took on a crucial ideological significance for those concerned about class relations and working-class unrest.

A writer quoted in The District Visitor's Manual, a manual designed to instruct women visitors on proper relations with the poor, stresses the important social-and political-role of such personal contacts:

It is, in truth, only by means of a more frequent and friendly interchange of feeling than has hitherto prevailed among the different orders of the community, that the bond of social union can be permanently strengthened. Thus alone may the more advanced civilization of the educated ranks be brought to bear upon the tone of morals and manners which pervade the nation at large; and thus alone can the higher classes acquire that intimate knowledge of the wants and habits of their inferiors, which will qualify them wisely to adapt their various plans of beneficence [a footnote adds, "May it not be added-or of legislation?"] to the real necessities of those whom they desire to serve.

Few among the rich are aware how easily they might thus surround themselves with an impregnable barrier of attachment,-a barrier which no political convulsion would be able to destroy. ${ }^{13}$

1 See J.F.C. Harrison, A History of the Working Men's College, 1854-1954 (London: Routledge and Kegan Paul, 1954).

12 Interestingly, manuals and other published advice to visitors often equate middle-class women's influence on servants in their own homes with their influence in the homes of the poor, although their relative position in the two situations is quite different. See, for instance, Charles Kingsley's popular lecture "The Country Parish," in Lectures to Ladies on Practical Subjects, ed. F. D. Maurice, 2d ed. (Cambridge: Macmillan, $\left.{ }^{8}{ }_{5} 6\right)$, p. 53 . Visiting, in some cases, was actually taken up as part of a program of finding or training good servants. See Jessica Gerard, "Lady Bountiful: Women of the Landed Classes and Rural Philanthropy," Victorian Studies, 30 (1987), 199; and Pamela Horn, The Rise and Fall of the Victorian Servant (Dublin: Gill and Macmillan, 1975), pp. $3^{6-37}$. For a discussion of middle-class women as mediators of class through their relations with servants, see Anne Summers, "A Home from Home-Women's Philanthropic Work in the Nineteenth Century," in Fit Work for Women, ed. Sandra Burman (New York: St. Martin's Press, 1979), pp. 33-63.

13 Christopher Benson, "A Sermon Preached in Behalf of the General Society for Promoting District Visiting," in The Distrnct Visitor's Manual, 2d ed. (London: John W. Parker, 1840), p. 31 . 
Not only were women visitors to shed their moralizing influence on the lower classes, but they were also to serve as the chief investigators of the working-class condition-"thus alone can the higher classes acquire ... intimate knowledge of the wants and habits of their inferiors." Despite the notoriety of male professional investigators like Henry Mayhew or Peter Gaskell, there were many more women in a position to observe the poor at first hand than there were men. Even organizations like the Charity Organization Society, which prided itself on its scientific and theoretically sound principles, relied on women visitors to do its fieldwork. Since women visitors were so vital to the work of the social-investigating, managing, and mediating relations between classes - it is not surprising that male professionals were anxious not only about what good or harm female visitors might do, but also about female competition within the social sphere.

While most people agreed that women visitors (at least when their visits were carried out properly) were important and necessary to harmonious class relations and to the smooth functioning of society, few would have actually advocated women's intervention in industrial class relations. Yet intervene is exactly what Margaret does in North and South. Although her initial effort to ward off violence by protecting Thornton is seen by most of the characters in the book as inappropriate and misguided, in her less public social role as a visitor Margaret does replace class conflict between Thornton and Higgins with personal contact. When Gaskell has Margaret teach Thornton, the factory owner, that he can initiate such personal contact with his employees in their homes as well as in the workplace, she is not merely idealizing or romanticizing industrial relations; rather, she is advocating a type of social management, pioneered by women in the social space of the home and based on firsthand knowledge of and practical experience with the poor rather than on the principles of political economy or other theoretical abstractions. Social management based on the personal contacts of women in homes is central to Gaskell's social vision. Margaret's mediations between groups with apparently opposed 
interests serve as a model of social action not just for women, but for both men and women as they operate within the sphere of the social. It is also significant that in Gaskell's novel the female visitor is not under the supervision of male professionals; in fact, her mediation is represented as superior to theirs.

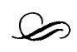

Visiting the poor had long been regarded as the province of ladies. Wives and daughters of the landed classes traditionally visited the poor on their estates and in the villages surrounding them, dispensing charity, giving advice, and exhorting the poor to religion. ${ }^{14}$ In North and South Gaskell idealizes this kind of charitable visiting for ladies in the Helstone sections, and when she has Margaret take up charitable visiting in industrialized Milton-Northern, Gaskell seems to some critics to urge a return to benevolent paternalism as the solution to urban class conflict. ${ }^{15}$ Margaret, however, is not simply an urban "Lady Bountiful." In her interactions with the Higgins family she quickly learns that the role of the benevolent patron is both inappropriate and ineffective in dealing with the urban working classes. As a visitor, she cannot simply dispense charity and reinforce deference, but rather must promote understanding and even intercede to prevent violence between "masters" and "men" involved in open class conflict of a kind hardly imagined in the rural South. Keeping the sympathy and sincere interest in the poor that she learned as a rural clergyman's daughter, Margaret modifies her attitudes and adapts her charitable practices to fit the new social

14 In her essay Gerard discusses the way in which the traditional rural "Lady Bountiful" role had a renewed ideological significance in the nineteenth century. "In their role as Lady Bountiful," she writes, "women of the nineteenth-century gentry and aristocracy reinforced the landed classes' rule over the rural poor, implementing paternalism and enforcing deference.... They made the personal contacts so crucial for maintaining the system of patriarchal control and deference" (pp. 183-84).

15 For instance, the thesis of Ivan Melada's The Captain of Industry in English Fiction, $1821-1871$ (Albuquerque: Univ. of New Mexico Press, 1970) is that nineteenthcentury industrial novels chart the progress of industrialists in assimilating the principles of paternalism. 
circumstances she encounters in the industrial North. Learning how to be a model female visitor, Margaret manages to reclaim the mediating role traditionally played by "Lady Bountiful" in an environment where relations between the classes are based on the "cash nexus"; in other words, she succeeds in commanding a central position in a set of market relations from which, according to the domestic ideology of separate spheres, she should be excluded.

It is significant that Margaret meets and begins visiting in a working-class neighborhood on her own accord. When she visits the Higginses, she does not come as an envoy of the landed gentry or of the church, as a Lady Bountiful would; neither does she visit as an emissary for a philanthropic association. Although some mid-nineteenth-century middle-class women did visit on their own authority, having Margaret do so in North and South is critical to the claims Gaskell is making for women's participation in the social sphere. Gaskell's female visitor is as exemplary as the Edinburgh Review claimed in her expert mediation between "masters" and "men," but her independent social action does not merely supplement the work of male professionals; rather, Margaret's class mediation complements and, in some cases, threatens to displace male professional contenders for authority in the social realm.

Unlike Margaret, most women visitors were representatives of some organization, either philanthropic or religious. Church-sponsored "district visitors" were assigned representatives of a parish clergyman and were deputed to assist him in carrying out his pastoral duties. In the wake of sweeping reforms that threatened the church's established position in English society, the clergy's pastoral duties had taken on a new significance by mid-century. ${ }^{16}$ Because the church faced challenges both from a reformed Parliament and from religious controversies within, the traditional gentrified clergy so often portrayed in earlier novels, like those of Jane Austen, had largely disappeared. They had been replaced by a newer, more professional clergy. Like other professional groups that

${ }_{16}$ See Anthony Russell, The Clerical Profession (London: SPCK, 1980), for a discussion of the changing role of the clergy during the nineteenth century. 
were also struggling to consolidate professional power by ousting "amateurs," the clergy shed many of its former practices, and clergymen attempted to consolidate their role as religious specialists or, as Anthony Russell expresses it, "the technologists of the sanctuary" (p. 4o). In addition, new stress was laid on the pastoral role of the clergy; the traditional allies of the gentry, the clergy came to be seen by many in the nineteenth century "as the main instrument for preserving the stability of the social structure"-in other words, for "mediating" between classes (Russell, pp. 162, 166). As "professional" mediators of class conflict, then, the clergy could be viewed as directly competing with women for this important role within the field of social relations. Since many middleclass women had the distinct advantage of having more time for pastoral visiting, it became a matter of critical importance to the clergy not only that women be taught the best way to deal with the poor they visited, but also that these women be kept under the umbrella of the church, where they would remain subordinate to and under the supervision of the professional male clergyman. ${ }^{17}$

Margaret Hale, however, is not a "district visitor"; her visits to the poor in Milton are not under the auspices of the clergy. Even though her own father is a former Church of England minister, he no longer holds that office and hence no

${ }_{17}$ The clergy's attempts to keep women's visiting under their control have been noted by most commentators on visiting and on the clergy. That this control was deemed essential is also readily apparent in virtually all the nineteenth-century manuals for district visitors. Both The District Visitor's Manual and Hints to District Visitors (London: Skeffington, $185^{8}$ ), for instance, include excerpts from "A Charge of the Late Bishop of London" (London, 1830) that specifically exhort the clergyman not to relinquish authority to women visitors: "it is incumbent upon me to caution the Parochial Clergy against relinquishing the superintendence and direction of these auxiliary laborers; and against delegating to them their own peculiar functions and duties, as the Commissioned Interpreters of Scripture, as the LORD's Remembrancers for His people, and as the appointed Guides of their devotion. There is a special promise of blessing annexed to ministerial service, and the sense of that speciality ought never to be effaced from the minds of our flocks, by the permitted intrusion of laymen however pious or zealous, into that which belongs to our own peculiar office" (Hints, p. ii). For a discussion of the attempt of the clergy to subordinate women visitors as part of their move toward professionalization, see Brian Heeney, The Women's Movement in the Church of England, 1850-1930 (Oxford: Clarendon Press, 1988). 
longer officially directs Margaret's philanthropic activities. Most critics of North and South have interpreted Mr. Hale's defection from the church simply as necessary to the plot, because it forces the family's removal from southern Helstone to Milton-Northern. ${ }^{18}$ Seen in the context of the struggle for access to the social space in which class conflicts are mediated, however, Mr. Hale's resignation from the established church is even more significant because it leaves that contested space clear for his daughter. Trained and advised by her father, Margaret nonetheless visits on her own authority. Margaret, in fact, is shown to be a better class mediator than her father. Although he does well with Higgins after Margaret brings the men together, Mr. Hale's own efforts toward mediating class tensions are portrayed as slightly ridiculous: agreeing to give a series of lectures for the workingmen's Lyceum, Mr. Hale chooses the unlikely subject of "Ecclesiastical Architecture." 19

Despite his kindly concern for his parishioners and for the working people of Milton, Mr. Hale's often-remarked gentlemanliness allies him more to the paternalistic past of his religious vocation than to the professional present. It is, at least in part, the liturgical emphasis of the newly professionalized clergy that puts Mr. Hale's doubts about the church's authority at issue; those who think of the clergy in the old-fashioned "gentlemanly" sense-notably his wife and her servant Dixon-cannot understand why such doubts should interfere with his clerical living, or even with his promotion to high church office. Their understanding of Mr. Hale's office as being primarily to serve as the first gentleman in the community (in the absence of a resident squire) is already at odds with a changing society. To take the depictions of Helstone in North and South, even in the early scenes, as a representation of a stable past order is to misread a significant facet of the world Gaskell's characters

18 Suzy Clarkson Holstein reads Mr. Hale's renunciation as Gaskell's challenge to patriarchal authority (see "A 'Root Deeper Than All Change': The Daughter's Longing in the Victorian Novel," The Victorian Newsletter, 75 [1989], 20-28). Stoneman offers a similar reading.

19 Gaskell, North and South, ed. Angus Easson (New York: Oxford Univ. Press, 1973), p. 141. Further references appear in the text. 
inhabit-a world complicated by numerous social changes. While some of these characters may indulge in a nostalgic idealization of Helstone and of the land-based economy it represents, such a vision of Margaret's home is relegated to the realm of a romantic fiction- "a village in a tale rather than in real life" (p. 12)-even before Helstone appears as a setting in the novel. By the time of Margaret's return to Helstone, in one of the final chapters of the novel, the displacement of the gentleman clergy by the new professional clergy is complete. Mr. Hepworth, the new vicar of Helstone, is a thoroughly modern-and professional-clergyman, renovating the parsonage, modernizing the charity school, and urging temperance on his parishioners. ${ }^{20}$

Mr. Hale is not the only person displaced by a more professional counterpart, however; Margaret finds that she too has lost "the important post of only daughter in Helstone parsonage" (p. 6). The school and visiting duties once performed by Margaret and her mother in the Lady Bountiful spirit are now discharged by Mrs. Hepworth, whose busy, self-important, businesslike manner is reminiscent of Dickens's Mrs. Pardiggle and represents what many objected to in the "district visitor."21 Mrs. Hepworth's attitude

20 Russell cites all of these activities as characteristic of the new professional clergy.

${ }_{21}$ Russell identifies a stereotype that Gaskell apparently utilizes in the Hepworths: "The picture of the managing clergyman and his formidable wife ruling the local community dates from this period" (p. 178). However, as Gerard indicates, rural Lady Bountifuls also arguably played a revitalized role in promoting the interests of the gentry during the mid nineteenth century. The bad or "dangerous" female visitor was perhaps best represented to the nineteenth-century popular imagination in Dickens's Mrs. Pardiggle. The response of the working man whom Mrs. Pardiggle visits indicates the negative effect on class relations that the wrong kind of visitor was feared to have: “ ‘. . make it easy for her!' growled the man upon the floor. 'I wants it done, and over. I wants a end of these liberties took with my place. I wants a end of being drawed like a badger. Now you're a-going to pollpry and question according to custom-I know what you're a-going to be up to. Well! You haven't got no occasion to be up to it' " (Charles Dickens, Bleak House, ed. George Ford and Sylvère Monod [New York: W. W. Norton, 1977], pp. 98-99). Margaret, unlike Mrs. Pardiggle, always treats those she visits with respect, courtesy, and gentle friendliness, always fearing to intrude and never prying or pushing advice on them. Margaret's interactions with the Higginses are always exemplary, and her character serves as an antidote to Dickens's negative caricature of the female visitor. 
toward her own duties may even suggest the concerns that some clergymen, including Charles Kingsley in his contribution to the Lectures to Ladies, expressed about clergy wives seeing pastoral work as a "joint-vocation." ${ }_{22}$ If so, the slightly unpleasant Mrs. Hepworth is set up as a figure on which to pin some of the anxieties that women philanthropists posed to professional men-especially the newly professionalized clergy - with whom they competed for ascendancy in the realm of the social.23 Pinning these anxieties on Mrs. Hepworth, of course, deflects them from Margaret and hence naturalizes her as the right kind of visitor.

If anxieties about women competing with the clergy for the role of class mediator are represented in the minor figure of Mrs. Hepworth, however, such anxieties are rather deeply hidden. They are more apparent, if also displaced, in Henry Lennox, who plays a somewhat larger role in the plot. Though not a clergyman, Lennox is clearly the representative professional man in North and South. He is also the male character most insistent on maintaining the separation of private and public spheres and keeping women securely within the home and out of social space. On his first appearance in the text Lennox insists on the difference between his professional work and the personal, domestic work of women:

"Well, I suppose you are all in the depths of business-ladies' business, I mean. Very different to my business, which is the real true law business. Playing with shawls is very different work to drawing up settlements." (p. 10)

While this opening remark is satirical-the satire is directed against himself as well as the ladies-it is consistent with his views throughout the novel. During the scene in which he proposes to Margaret, for instance, Lennox characterizes himself as unromantic, prudent, and worldly; his love for Margaret is "the one outlet which he has formed for the deeper and

22 In "The Country Parrish" Kingsley writes, "It is said that a clergyman's wife ought to consider the parish as her flock as well as her husband's. It may be so: I believe the dogma to be much overstated just now" (Lectures to Ladies on Practical Subjects, pp. 55-56).

${ }_{23}$ The Edinburgh Review article alluded to such "anxieties." 
better feelings of his nature" (p. 3o). The "worldly" Lennox is a public man; Margaret, who brings out his "better feelings," is the angelic domestic woman, the repository of values deemed inappropriate to "a struggling barrister." Lennox almost unfailingly identifies himself with strong, professional menincluding the new vicar of Helstone, "a clever, sensible man, and a thoroughly active clergyman" (p. 380)-while what he most wants from his prospective wife is dependence: "His eye brightened with exultation. How she was learning to depend upon him!" (p. 433). Lennox seems to desire a relationship in which, although Margaret might continue her London-based charitable visiting (such would be quite consistent with the role of a professional's wife), she would be supervised and directed by her husband and/or other male professionals. While she might operate within the social sphere, her role would be an extension of her private role, not an independent role within a social space defined as both private and public.

Margaret does not marry Lennox, however, and her father leaves the church, thus allowing her to enter the social sphere as an autonomous visitor of the poor and as the wife of an entrepreneur who is open to female influence, even female intervention, in his social relations. In order to solidify her claims for women's access to the social realm, however, Gaskell not only clears away "professional" competitors but also demonstrates the efficacy of women's mediation between opposing interests.

\section{e}

For many people in the nineteenth century, the key role of the woman visitor was the same as her most important home duty - she was to use her "influence" to promote morality and domestic happiness. Though she might use this vaunted influence to motivate the men of her family to look more sympathetically on the poor or on their own employees, a woman's major effect was conceived to take a downward direction-on her servants and those she visited. While neither Gaskell nor the other advocates of women's social work would have discounted the power of a woman's influence, for 
them the concept of social mediation went beyond a merely downward moralizing tendency. Mediation, as conceived in North and South, involves using women to represent the potentially opposed interests or experiences of different groups to each other. For Gaskell this means that it is women's social duty to manage the interpretation of signs. ${ }^{24}$

In her dissertation on the British industrial novel, Patricia Johnson says of North and South that "the characters spend a lot of time arguing about word choices, definitions, and analogies" (p. 143). Their difficulties with language, argues Gallagher, manifest an "anarchy of signification" (p. 181) that the novel intends but fails to overcome through the "metonymic substitution of family for society" in the marriage of Margaret and Thornton (p. 183). While Gallagher is certainly right that signification repeatedly misfires in North and South, I would argue that it is not Margaret's marriage but rather her social mediation-which comes about through philanthropic visiting - that is meant to answer the crisis of signification that inevitably occurs with rapid social change.

Although Margaret displays most of the characteristics associated with the ideal lady visitor as described in numerous manuals, sermons, and books of advice, she does encounter some difficulties in her intercourse with the working-class Higgins family. Her difficulties arise not from her lack of sympathy or moral capacity but from her failure to understand the Higginses' words and gestures. In one of Margaret's interchanges with Bessy, for instance, Bessy laments that she has sent her father out of the house and to "the folk that are always ready for to tempt a man, in time o' strike, to go drink" (p. 136). Margaret responds, with some alarm, "But does your father drink?" to which Bessy answers, "No-not to say drink." Margaret automatically associates "drink" with perpetual drunkenness, a sign of the rebellion and spendthrift recklessness of the poor, and Bessy has to explain to Margaret what drink means in working-class culture. "Father never was a drunkard," stresses Bessy, "though maybe, he's got worse for drink, now and then." For Bessy, "drink" is only

${ }_{24}$ Schor also discusses Margaret's role as "textual transmitter," to a somewhat different purpose (p. 121 ). 
dangers." However well-intentioned, visitors may antagonize the poor who will "come to regard themselves as the inspected" and who may pretend to be worse off than they are in order to receive charitable donations. Proper visitors, on the other hand, can foster much goodwill between classes:

Once in a while a visitor may mediate between the master and the man. So the circle widens and spreads, and who can tell the misery which that one kind woman's call may have averted? And here it is impossible not to allude to a work most fruitful in suggestion on this subject. We mean that part of Mrs. Gaskell's 'North and South,' which portrays the gradually acquired ascendancy of Margaret over the radical and infidel weaver, Nicholas Higgins. The more nearly it is examined, the more genuine and free from blemish does this picture appear. Humility and deep sympathy, on one side, meet in time with the due abatement of pride on the other: the whole coming quite within the range of ordinary probabilities.

(p. 370)

As an antidote to the anxieties posed by the figure of the female visitor, the reviewer proposes a novel: Elizabeth Gaskell's North and South, published serially in Charles Dickens's Household Words in 1854-55 and issued in two volumes in 1855. According to the reviewer, Gaskell's novel resolves the disturbing paradox-the double danger of the woman visitor-by portraying a model lady visitor who performs the vital function of mediating between classes with feminine "humility and deep sympathy." Her visits to the poor are not dangerous because they do not jeopardize the relations they are supposed to be mediating. Just as significantly, the model lady visitor, as described by the reviewer, does not threaten the position of the paid male professional; while the effects of the "kind woman's call" are important, their value is incalculable and therefore outside of the professional market where such services are bought and sold: "who can tell the misery which . . . may have [been] averted?"

This critic's brief review of North and South identifies a crucial aspect of the novel that later critics have almost entirely passed over. Although twentieth-century critics have read North and South as a "social problem" novel or as an "industrial" novel, no one has considered it in the context of the mid- 
a potential hazard, an occasional drink being a normal part of working life. Although Margaret now understands the working-class distinction between "drink" and drunkenness, she experiences more difficulty when she in turn must interpret working-class "drink" for her father. When she brings Higgins home to meet her father immediately after Bessy's death, Margaret, fearing that Mr. Hale will automatically recoil from her friend, tries to explain that Higgins is only partly inebriated. She finds herself at a loss, however, to describe Higgins's exact state to Mr. Hale without calling up the image of the "drunken infidel weaver" (p. 223).

Another example of how crucial it is for Margaret to correctly interpret and value working-class language occurs when Mrs. Hale accuses Margaret of vulgarity because she has adopted "factory slang" (p. 237). Margaret's answer reveals how thoroughly she has come to understand the language of the people she visits: "And if I live in a factory town, I must speak factory language when I want it. Why, mamma, I could astonish you with a great many words you never heard in your life. I don't believe you know what a knobstick is." Margaret's openness to new languages and her willingness to learn new ways of interpreting signs is key to her success as a mediator of social conflict.

The significance of learning to understand others' language and correctly read their signs is demonstrated in Thornton's description of his social "experiment," a cooperative dining room managed by his employees. Thornton explains to Mr. Colthurst, a Member of Parliament, that such schemes must be "carried on by that sort of common interest which invariably makes people find means and ways of seeing each other, and becoming acquainted with each other's characters and persons, and even tricks of temper and modes of speech. We should understand each other better, and I'll venture to say we should like each other more" (p. 432; emphasis added). Becoming familiar with others, reasons Thornton, teaches one to read the sign systems of their dress, demeanor, gestures, and speech; correctly reading these signs leads to understanding; and understanding leads to affection. People who like each other are no longer enemies, are no longer 
locked in conflict. Thornton, of course, has acquired this "wisdom" through his dialogues with Margaret.

To be a social mediator Margaret must be able to understand and communicate in both directions. In the various dialogues in the novel she alternately represents Thornton's opinions to Higgins and Higgins's opinions to Thornton. Margaret is not merely a conduit between the two men, however. Each time she speaks to either of them, she, the "master" of both languages, interprets and translates the men's opinions. The "force connecting public and private life" comes not only from Margaret's "moral influence," as Gallagher would have it (p. 168), but also from her role as ideal reader and interpreter of both personal and public discursive practices. This is a social role that is informed by and yet more than the personal and domestic. It is often Margaret who brings order to the "anarchy of signification," precisely because she comes to accept and adapt to the social changes registered in language.

Although Margaret serves as an exemplary mediator by translating the languages of men to each other, even she sometimes fails to read or to be read properly. The whole Thornton family, of course, repeatedly misconstrues Margaret's actions and language, while she sometimes misreads their intentions as well, particularly in the case of Mr. Thornton. For instance, he takes offense at Margaret's omitting to shake his hand at the conclusion of a visit-a social custom among his set but not hers. When she finally performs this social gesture, he has come to understand it as the mark of intimacy that she takes it to be. Margaret and Thornton, after much discussion, finally come to share each other's definition of the word "gentleman." As it does with Thornton and his men, becoming familiar with each other's language-_characters and persons, and even tricks of temper and modes of speech"-leads Margaret and Thornton finally to understanding and to mutual affection, even love, but they encounter many difficulties along the way. Margaret and Thornton, of course, do not perceive their misreadings of each other; since they lack the language to read the signs correctly, they cannot know about these mistakes until later, when they acquire the requisite information. The 
reader, however, does recognize these scenes of linguistic misunderstanding. When Margaret fails as a mediator, the novel itself provides the language that enables the reader to correctly interpret the characters' signs.

Similarly, although the course of her relationship with the working-class Higginses runs much smoother than it does with Thornton, Margaret sometimes misreads their signs as well-also without knowing it. For instance, on one of Margaret's early visits to the Higginses, she notices that Mary has made a large fire, despite the hot weather. Margaret assumes that this fire is owing to Bessy's fevered condition; the narrator, however, informs us that the fire is actually a working-class sign of hospitality meant to welcome Margaret. While her misreading here does not lead to any particular consequences, it is an example of something that both occurs repeatedly in the novel and characterizes the narrative structure: the narrator is the model reader of signs, who knows the languages of all the characters and who interprets those signs for the reader. Thus, like Margaret, the narrator mediates between groups who do not understand-and may not like-each other.

To read North and South is to read a series of debates, of contrasting scenes, of alternated speeches. Each chapter of dialogue between Margaret and Thornton is placed next to a dialogue between Margaret and Higgins; each description of Bessy's illness is followed by a description of Mrs. Hale's illness; the Hales' visit to the Thorntons is contrasted with the Thorntons' visit to the Hales; even Margaret's public appearance at the strike scene is set against Mrs. Thornton's own, more private intervention in a strike (p. 116). The narrator, like Margaret, presents and interprets all these contrasting situations for the reader. Following the model of social mediation that North and South offers, we are expected to believe that if the reader becomes familiar with the different signs and languages of class-particularly the working class, but almost as importantly the new industrial class-then the reader will understand and like, or feel new interest in and sympathy for, the generators of those signs. ${ }^{25}$ The narrator

${ }_{25}$ Schor makes a similar point when she suggests that the novel "posit[s] the literary text as the object that moves between masters and men, that will lead them to the sympathy that in turn brings about reform" (p. 137). 
conspicuously refrains, for the most part, from taking sides; she presents, she interprets where necessary, and thus she brings together. The solution is provided neither by one side nor the other but always by a moderating position-and this solution is always reached through two vehicles: language and sympathy. While both Thornton and Higgins attempt to handle class conflict with force, such tactics, Gaskell tells us, are doomed to failure. It is only through talk and through personal acquaintance that class conflict can be changed into class harmony.

Thus Gaskell's talky novel about the mediation of opposing interests, which are represented in the very title of the book, claims access to the social sphere for women visitors and for women novelists. Not merely intended for entertainment, to generate tears in the family circle around the fireside, North and South is presented as a novel that not only addresses social problems but enacts the very process recommended in it. In effect, through the portrayal of an exemplary woman visitor, the novel constructs a social space that is neither wholly private nor wholly public but is based on the powerful effects of the control over language-and then it inhabits that space. Gaskell's novel makes claims for its own contribution to the public discourse. Journalists and philosophers become, in a sense, the "theorists" of the writing profession; the sentimental novel occupies the private sphere, but the social-problem novel that joins social theory and personal experience is the ideal discourse of the social. By writing a social-problem novel that functions in the publishing world like Margaret does as a female visitor, Gaskell claims authority for herself and other middle-class women to enter public debates about social and political issues, not despite, but rather because of, their position as domestic women. Not unpredictably, however, women's access to the social does not come without a cost, one that North and South makes evident.

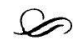

In the midst of one of the discussions of language in North and South-specifically, a discussion about the use of the child-parent metaphor to represent labor and 
class relations-Margaret relates an anecdote about a man who for forty years kept his son in a childlike state in order to protect him from the temptations of the world. "His father," says Margaret, "had made the blunder of bringing him up in ignorance and taking it for innocence; and after fourteen months of riotous living, the city authorities had to take charge of him, in order to save him from starvation" (p. 121). Margaret's analogy inflicts the deathblow to the metaphor that she and Thornton have been arguing over; Thornton complains that Margaret, in this anecdote, has used the parent-child metaphor as a weapon against him, and they henceforth reject it completely as a model for class or labor relations. ${ }^{26}$

Although its narrative method depends on dualities like parent and child, masters and men, and North and South, the novel also rejects, or deconstructs, the polarity of such dualities because, as we have seen, it aspires to construct a ground on which dualities can meet and be mediated. By demolishing the parent-child metaphor, North and South argues for adult-to-adult interactions on common ground.27 Rather than doing away with metaphor, however, Gaskell's novel offers another metaphor to replace the historically loaded metaphor of paternalism. Although it implies a different kind of power relation, one of adult to adult, it is still not a metaphor of equality. The metaphor that North and South offers to replace the paternal model for class relations is, of course, marriage. That it uses this alternative metaphor has implications not only for relations between masters and men but between men and women as well.

The metaphor of marriage as a model for class relations works in Gaskell's novel because of the identification she establishes between women and the working class. This identification underwrites the common claim that women are ideal

${ }^{26}$ Bodenheimer (pp. 57-58) and Gallagher (pp. 167-68) also point to this rejection of the parent-child metaphor as a rejection of paternalism.

$27 \mathrm{Mr}$. Hale tries to suggest adolescence as a substitute for the child half of the paternalist analogy for class relations, but this, too, is rejected because, as Margaret claims, adolescence is still childhood in the sense that the parent, however much independence he is willing to grant, still holds all the power. 
mediators of class conflict. ${ }^{28}$ Not only were women to serve literally as mediators through personal contact with the working classes in their roles as mistresses of servants and as visitors to the poor, but the concept of women as mediators provided a way to manage middle-class anxieties about the "problem" of the lower classes. In fact, because women were like the working classes, they could stand in for the working class; if women could be managed, the dangerous working classes could also be kept under control.

Like women, the working classes were represented as unruly, ignorant (equated in Margaret's Nuremberg anecdote with "innocent"), and sexual. When Margaret first travels the streets of Milton she is "very unfortunate in constantly falling in" with the factory workers:

They came rushing along, with bold, fearless faces, and loud laughs and jests, particularly aimed at all those who appeared to be above them in rank or station. The tones of their unrestrained voices, and their carelessness of all common rules of street politeness, frightened Margaret a little at first.... she alternately dreaded and fired up against the workmen, who commented not on her dress, but on her looks, in the same open fearless manner. (p. 71)

"Bold," "fearless," "loud," "unrestrained," and "careless" are words that call up the figure of uncontrolled female sexuality - the prostitute. The prostitute is the woman who is "unrestrained" and "careless of all common rules"; she is the woman not kept in check within the domestic sphere. Not only are the working-class men frankly sexually aware, but their behavior is like an unrestrained woman. The "disorderly tumult" that reigns in the working-class streets is contrasted to "the quiet safety of home" (p. 72), where Margaret is not only safe but free of sexual innuendo. Although her position in a middle-class home allows Margaret to deny her sexuality until nearly the last page of the novel, others-Henry Lennox, Mr.

${ }_{28}$ Bodenheimer makes a similar argument about a number of industrial novels: "The middle-class heroine is also in a structurally double relation to working-class characters, figuring the latent social power of both classes while robbing it of its destructive power" (p. 18). Kestner makes a more literal connection by claiming that "women identified [themselves] with the disenfranchised working classes" (p. 3). 
Thornton, Mrs. Thornton and her servants-clearly recognize it. Not only do they appreciate that Margaret is a woman, and hence a sexual being, they also realize that her sexuality has the potential to be unruly and unrestrained. Mrs. Thornton twice interprets activities Margaret defines as pure and noble as sexually motivated (the riot and her walk with Frederick), and Mr. Thornton has a dream in which he sees Margaret as a lascivious and loose woman, and he reads her lie as an admission of sexual misconduct. Although Margaret's sexual, and potentially unruly, nature is constantly kept in check by the "common rules" of courtesy or by the manners and conventions of her class, the only way to ensure her "modesty" is through marriage. ${ }^{29}$

Women's position in marriage entails another likeness to the working class. Like the "hands" in the factory, married women were in a subordinate position-and they were excluded from ownership of property. Since marrying a woman was the socially and legally sanctioned way for middle- and upper-class men to control women's money, labor, and sexuality, marriage was a particularly useful metaphor for representing the management of the lower classes. In North and South the chief power that both women and workers have is to refuse to submit to such control-to withhold either their labor (figured as a strike, in the case of the workers) or their sexuality (figured as the refusal to marry, in Margaret's case). $3^{\circ}$ Before Margaret yields herself to Thornton in marriage, he reports to her that his men have sent him a "roundrobin" pledging their labor to him if he is ever "in a position to employ [them] again" (p. 432). Their "round-robin" bears a structural similarity to a marriage vow. A few pages later, both Thornton's men and his woman are pledged to honor and obey him.

29 On Victorian women and modesty, see Ruth Bernard Yeazell's "Why Political Novels Have Heroines: Sybil, Mary Barton, and Felix Holt," Novel, 18 (1985), 126-44, as well as her full-length study, Fictions of Modesty: Women and Courtship in the English Novel (Chicago: Univ. of Chicago Press, 1991).

3o In the eighteenth century, interestingly, it was sexuality rather than labor that the working classes were represented as withholding. No one feared that the laborers would not work, but rather that they would not have enough children to stoke the nation's economic prosperity and military strength. 
Significantly, however, neither the marriage of man and woman nor of "master" and "hand" is characterized as complete victory on the one side or as complete submission on the other. Thornton acknowledges that his new relations with his men are not likely to prevent future strikes but only to make strikes "respectable." Margaret grabs the Helstone roses (roses are a traditional metaphor for sexuality) from Thornton with "gentle violence" (p. 436). The use of these two oxymorons, "respectable strike" and "gentle violence," marks an important qualification of the work that marriage is supposed to accomplish as a metaphor, because it leaves some power in the hands of the weaker partner. The trope of "gentle violence," in fact, would seem more appropriate to the mystification of the power of masters and husbandsmasters who call in soldiers to suppress strikes and husbands who possess the legal means to render women virtually powerless. Yet Gaskell uses this trope to describe Margaret's action. Instead of changing laws or overturning existing power structures, Gaskell offers a social vision that tempers power relations with mutual understanding and affection.

Thus, although Mr. Bell playfully accuses Margaret of being "a democrat, a red republican, a member of the Peace Society, a socialist" (p. 330), Gaskell's novel offers love and marriage instead of revolution, socialism, or feminism. Including these politically charged terms in Mr. Bell's jest, in fact, is a way of rejecting them as absurd alternatives for handling the social problems with which the novel is concerned. Instead, Gaskell uses marriage, the conventional novelistic ending, as a statement of her proposed social agenda. The very conventionality of the "happy ending" serves as a mask that naturalizes what is unconventional in her vision of women's role.

Although the marriage at the end of North and South is a novelistic convention, the marriage itself is not conventional, at least within the terms of the genre. Indeed, the kind of marriage that Margaret and Thornton create is as important to Gaskell's purpose as is the fact of their marriage. While we do not know what exactly their marriage is like, since the novel ends even before the wedding, we do know, presumably, what 
it is not like, because at least four different models of marriage are presented-and rejected-in North and South. The marriage of General and Mrs. Shaw, for instance, is a marriage of convenience, contracted on the basis of exchange of property and rank. Mrs. Shaw herself rejects this kind of marriage and insists that her daughter, Edith, marry for love. Margaret, however, finds Edith's society marriage disturbing; she notices disapprovingly that Captain Lennox is "anxiously attentive to Edith's dress and appearance, with a view to her beauty making a sufficient impression on the world" (p. 373). Margaret also rejects her own proposed marriage to Henry Lennox. Although she and Henry share many tastes and sympathies, his vision of marriage rests on the separation of men's and women's spheres and on women's confinement to the domestic. Her parents' marriage is based on love, but Mr. and Mrs. Hale nonetheless seem unable to communicate with each other on even the most important matters affecting their life together-his leaving the church and her terminal illness. By contrast to these rejected models of marriage, all grounded in the separation of men's and women's spheres, the relationship of Margaret and Thornton follows the formula that North and South gives for class harmony: familiarity with the other's language leads to understanding, which leads to affection and cooperation. Further, Thornton's home, where Margaret will presumably live, is not removed from the scene of labor and class relations like most middle-class homes; it sits on the same ground as the factory, so that Margaret will not inhabit an entirely "separate sphere" from her husband..$^{x}$ Like the dining room that domesticates the factory, Margaret's home blurs the boundaries between the public and private spheres; presumably her marriage will follow suit.

The "happy ending" of North and South is not merely the lapse into the personal that marks Gaskell's failure to sustain

31 A letter Gaskell wrote during the composition of North and South indicates that she thought of having Thornton's mill and house burn so that Margaret "need not go \& live there when she's married." For whatever reason, however, she did not make this change, and thus presumably Margaret does need to "go \& live there" following her marriage (letter 211 , to Catherine Winkworth, 11 to 14 October 1854 , in The Letters of Mrs. Gaskell, ed. J.A.V. Chapple and Arthur Pollard (Cambridge, Mass.: Harvard Univ. Press, 1967), p. $3^{10 .}$ 
a critique of social relations, nor is it an argument for "the continued isolation of the family from society" (Gallagher, $p$. 148). The marriage of Margaret, the lady visitor, and Thornton, the progressive industrialist, is Gaskell's metaphor for the newly constructed social sphere. The metaphor demonstrates both the possibilities and the limitations of that space for middle-class women. While by mid-century women like Gaskell had unquestioned access to the social sphere through writing for publication, visiting, and other philanthropic activities, they did not have full autonomy, even within that sphere. Yet the construction and "feminization" of the social sphere, as Riley observes (see pp. 48, 54-55), was a precondition for women's entry into the commercial and political spaces that occurred a few decades later. Because it both portrays women mediating social relations and itself performs an act of mediation, North and South looks to the future, and not to the past, of class and gender relations.

Johns Hopkins University 
nineteenth-century debate about female visitors to the pooran issue it obviously raised for contemporary readers. ${ }^{2}$ Modern critics who read North and South for its social commentary, from Louis Cazamian's 1903 The Social Novel in England to Sally Minogue's 1990 essay "Gender and Class in Villette and North and South," commonly fault Gaskell for failing to follow through with the potentially radical implications-Marxist or feminist-of the social issues she raises in North and South. Specifically, such critics object to the novel's "happy ending," which is almost universally read as a retreat from the troubling problems of the public sphere into a romanticized private and personal reconciliation. 3 John Lucas, in The Literature of

2 Louis Cazamian, in his The Social Novel in England 1830-185o: Dickens, Disraeli, Mrs. Gaskell, Kingsley, trans. Martin Fido (1903; rpt. Boston: Routledge \& Kegan Paul, 1973), was the first to write about North and South as a "social problem novel."

3 The most well-known Marxist readings of North and South are Arnold Kettle's "The Early Victorian Social-Problem Novel," in From Dickens to Hardy, vol. 6 of A Guide to English Literature, ed. Boris Ford (Harmondsworth: Penguin, 1958); and Raymond Williams's Culture and Society, 1780-1950 (London: Chatto and Windus, 1958). Other critics who read North and South primarily in terms of the social problems of class and industrialization include Coral Lansbury, Elizabeth Gaskell: The Novel of Social Crisis (New York: Barnes and Noble, 1975); Patrick Brantlinger, The Spirit of Reform: British Literature and Politics, $1832-1867$ (Cambridge, Mass.: Harvard Univ. Press, 1977); John Lucas, The Literature of Change: Studies in the NineteenthCentury Provincial Novel (Totowa, N.J.: Barnes and Noble, 1980); and Joseph Kestner, Protest and Reform: The British Social Narrative by Women, 1827-1857 (Madison: Univ. of Wisconsin Press, 1985). For examples of feminist readings, see Françoise Basch, Relative Creatures: Victorian Women in Society and the Novel, trans. Anthony Rudolf (New York: Schocken Books, 1974); Deirdre David, Fictions of Resolution in Three Victorian Novels: "North and South," "Our Mutual Friend," "Daniel Deronda" (New York: Columbia Univ. Press, 1981); Pauline Nestor, Female Friendships and Communities: Charlotte Brontë, George Eliot, Elizabeth Gaskell (Oxford: Clarendon Press, 1985); Catherine Gallagher, The Industrial Reformation of English Fiction: Social Discourse and Narrative Form, 1832-1867 (Chicago: Univ. of Chicago Press, 1985); Patsy Stoneman, Elizabeth Gaskell (Bloomington and Indianapolis: Indiana Univ. Press, 1987); Rosemarie Bodenheimer, The Politics of Story in Victorian Social Fiction (Ithaca: Cornell Univ. Press, 1988); Susan Morgan, Sisters in Time: Imagining Gender in NineteenthCentury Brttish Fiction (New York: Oxford Univ. Press, 1989); Sally Minogue, "Gender and Class in Villette and North and South," in Problems for Feminist Criticism, ed. Minogue (New York: Routledge, 1990), pp. 70-108; Deanna L. Davis, "Feminist Critics and Literary Mothers: Daughters Reading Elizabeth Gaskell," Signs, 17 (1992), 507-32; Hilary M. Schor, Scheherezade in the Marketplace: Elizabeth Gaskell and the Victorian Novel (New York: Oxford Univ. Press, 1992). See also two unpublished dissertations: Patricia Ellen Johnson, "The Role of the Middle-Class Woman in the Mid-Nineteenth-Century British Industrial Novel," diss., Univ. of Minnesota, 1985; and Susan Ruth Zlotnick, "Women Writers and the Industrial Revolution: History, 
Change, for instance, accuses Gaskell of "laps[ing] into cosy liberalism" (p. xiv), while even Minogue, a feminist trying to rehabilitate Gaskell, maintains that "the ending belies the emotional, social and moral complexity of the novel" (p. 76).

Catherine Gallagher, Rosemarie Bodenheimer, and Hilary Schor complicate these narratives of failure by focusing on the dynamics of the relation between the public and private spheres throughout the novel. For Gallagher, the "metonymic method of connecting the public and private spheres ... paradoxically depends on their separation. The novel's solution hides but does not resolve this basic dilemma" (p. 178). While Gallagher's reading is quite convincing, even her account misrepresents Gaskell's novel because it tends to oversimplify notions of the public and private in the mid-nineteenth-century England portrayed in North and South. What Gallagher fails to recognize is that many of Margaret's "private" or "personal" actions are already coded with a public meaning, a meaning that comes out of the controversy about female visiting. Schor's astute analysis of Margaret Hale's social function recognizes her mediating role between public and private spheres, but concludes that Margaret's "woman's plot is in danger of getting subsumed in the larger plots (the social conversation, the industrial debate, the ideological imperatives of marriage)" (p. 144). By not noticing the text's references to Margaret as a "female visitor," Schor fails to recognize the way in which Gaskell's novel attempts to construct a social sphere that casts a "woman's plot" as one of those "larger plots." Bodenheimer contends that Gaskell's "refusal to keep [the heroine] 'pure' and separate from the activities generally associated with the male, the public, and the system" enables her to find "an enabling structure within the model of capitalist enterprise itself" (p. 67). Bodenheimer's reading is essentially right, but even she does not take into account the crucial role of the female visitor in constructing that "enabling structure."

Class, and Gender in the Victorian Factory Novel," diss., Univ. of Pennsylvania, 1989 . 
As the Edinburgh Review article indicates, the representation in North and South of a lady visiting in a working-class home was embedded in a controversy of considerable moment in mid-century England, a controversy on one level over whether and how the poor were to be reached, supervised, and taught proper values. On another level the question of ladies' visiting was a contest over who had access to and who would control a whole range of social spaces and practices. Reading North and South as Gaskell's attempt to resolve imaginatively some of the issues involved in the controversy over female visiting allows us to make sense of some of the more troubling aspects of the novel, including its "happy ending," and sheds light on the cultural work that Gaskell's novel performed in mid-nineteenth-century England.

As the Edinburgh Review writer maintained, North and South does represent an exemplary woman visitor, and it makes some important claims about her fitness for the role of mediator between classes; it also presses those claims against those of various male professionals. Gaskell's novel, however, goes even beyond claiming the publicly useful role of class mediator for women; in rewriting the upper-class woman's traditional role as "Lady Bountiful" for an urban setting, Gaskell offers a new model of social relations that is based neither on rural paternalism nor on the industrial "cash nexus." In Gaskell's version of society, women play a vital role in the newly defined social sphere, a space that is both private and public. Gaskell's social model also enables her to extend her claims for women visitors to include women novelists. Her novel is not only about philanthropic visiting; using its narrative structure as a model of the mediating role it projects for women visitors, North and South represents the writing of a novel as a philanthropic act akin to visiting. In claiming an independent, autonomous role for women in the social sphere, however, North and South does not challenge the private arrangements of the domestic sphere where men rule over women legally, sexually, and emotionally; in fact, the novel bases its case for women's mediation between classes on an analogy between marriage and class cooperation. 


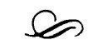

The social sphere, as it was constructed in the nineteenth century, was both an ideological and a material space. Ideologically and practically, the social sphere fell between what were defined as public and private spheres and blurred the boundaries between them. Thus, although the domestic ideology that promoted the privatized and feminized home as a separate sphere and a refuge from the hostile public world of men was accepted as natural and true in nineteenth-century England, neither the public nor the private sphere was as unified or discrete as it seemed.4 Moreover, both public and private spheres were also internally divided. What is usually called the public sphere, for example, was actually an aggregate of diverse activities and interests encompassing government, education, business, manufacturing, science, and the arts. While all of these activities might have been characterized as public, and therefore part of the man's appropriate sphere, not all men had equal access or authority in any or all of these areas. In fact, the various "sub-realms" vied with each other for primacy and power within the larger sphere of the public; all, however, defined themselves as public by their difference from activities marked as private by being associated with women. While the political and public had almost always been synonymous, and the commercial or economic realm had long been recognized as a public domain, the social realm was a relative newcomer to the public sphere.

Historian Denise Riley describes some of the activities that characterized the "newly conceived space" of "the social":

The nineteenth-century "social" is the reiterated sum of progressive philanthropies, theories of class, of poverty, of degeneration; studies of the domestic lives of workers, their housing, hygiene, morality, mortality; of their exploitation, or their need for protection, as this bore on their family lives too. It is a blurred ground between the old public and private, voiced as a field for interven-

4 Several recent critics, including Gallagher and Bodenheimer, have also pointed out that the public and private spheres were never as separate or autonomous as nineteenth-century thinkers assumed they were. 
tion, love, and reform by socialists, conservatives, radicals, liberals, and feminists in their different and conjoined ways. 5

While Riley uses spatial terms such as "ground" and "field" metaphorically to describe the ideological work "the social" was supposed to accomplish, the nineteenth-century social sphere also had its material spaces-the tenements and cottages of the poor, the streets and sewers of the cities, the lanes and bogs of the country, and the comfortable rooms of the middle-class home. The social, with its "theories" and "studies," could be classified as a public realm because it was associated with the middle-class male professional and his expertise. However, because the object of social observation and intervention was the family, women too could be represented as "experts." The private home itself was defined by the newly constituted "social science" as a public space that was both political and apolitical, commercial and antimarket. ${ }^{6}$ All women's work, even that strictly isolated within the home, could now be defined as social or, in other words, as at least partly public. And when a middle-class woman left her own home to visit in the homes of the poor, she used her domestic "expertise" to authorize herself as an expert, masculinized observer of the social. Since all sorts of concerns identified as public-industrial relations, political unrest, regulative legislation, sociological investigation, and scientific experimentation-fell under the rubric of the social, it was thus possible to imagine these realms as appropriate work for women. Although the social may have been in one sense inherently feminized, it was by no means automati-

5 "Am I That Name?": Feminism and the Category of "Women" in History (London: Macmillan, 1988), p. 49 .

6 The National Association for the Promotion of Social Science was founded only two years after the publication of North and South. A number of liberal thinkers and reformers participated in its annual congresses. Women, too, played a conspicuous role in the society's meetings and publications. Frances Power Cobbe defended women's participation in the new field of social science in an article for Macmellan's (see "Social Science Congresses, and Women's Part in Them," Macmillan's Magazine, 5 [1861], 81-94; rpt. in Free and Ennobled: Source Readings in the Development of Victorian Feminism, ed. Carol Bauer and Lawrence Ritt [Oxford: Pergamon Press, 1979], pp. 84-88). 
cally ceded to women.7 Rather, as the Edinburgh Review article implies, professional men and middle-class women competed for access to and authority over the social sphere. North and South helped to construct this social sphere and to claim it for exemplary women visitors like Margaret Haleand for women novelists like Gaskell.

In the mid nineteenth century, one major project of what I am calling the social sphere was to heal the "separation between class and class which is the great curse of British society," as Justice Talfourd expressed it in his last speech in $1854 .^{8}$ Although the immediate fears of political and social upheaval that many in the middle classes had harbored during the $184 \mathrm{os}$ had declined with the demise of Chartism and the touted prosperity of the $185 \mathrm{os}$, a wave of strikes beginning in $185^{2}$ provided an occasion for some middle-class writers and thinkers to reopen debates about class relations. This was especially true in industrial areas (particularly those surrounding Manchester), although strikes occurred in many places around the country, including at least one by agricultural workers in a rural area.

Gaskell, of course, lived in Manchester, the heart of the manufacturing district where the majority of strikes were occurring, and North and South was her explicit contribution to the discussion of strikes and labor disputes. Perhaps the most famous strike was the Preston Strike, or "lockout," which began in the summer of 1853 and lasted until the spring of 1854 , while Gaskell was writing North and South.9

7 Riley claims that the social was inherently feminized (p. 50 ), but in order to make this claim she conflates the positions of the masculinized expert and the feminized object of social observation. When women took up the position of expert they were taking up a masculinized position. Although Riley is right to observe that women had easier access to the social realm because the object of investigation was feminized, her assumption that the social was "doubly feminized" obscures the struggle for social authority between male professionals and middle-class women.

${ }^{8}$ Quoted in "The Late Mr. Justice Talfourd," Law Magazine, n.s. 20 (1854), 323.

9 For an account of the 185 os strikes, especially the Preston Strike, see H. I. Dutton and J. E. King, "Ten Per Cent and No Surrender": The Preston Strike, 1853-1854 (Cambridge: Cambridge Univ. Press, 1981). For more extended discussion of Gaskell and the Preston Strike, see Geoffrey Carnall, "Dickens, Mrs. Gaskell, and the Preston Strike," Victorian Studies, 8 (1964), 31-48; and Patrick Brantlinger, "The Case against Trade Unions in Early Victorian Fiction," Victoraan Studies, 13 (1969), $37-5^{2}$. 
According to Henry Ashworth, one of the commentators on the much-discussed Preston Strike (writing on the side of the "masters"), the working classes were dangerous precisely because they began striking not when times were bad, as they were in the 1840 , but in a period of economic prosperity. In Ashworth's view the more the workers got, the more they wanted; the strike was not about wages but about power and property. What the working classes-and their middle-class sympathizers - want, claims Ashworth, is "to reconstruct society on a new basis":

The right of the master... rests upon the principle that he may do as he likes with his own money; it is, in fact, a necessary consequence of the rights of property. If any body of workpeople may justly dictate the limits within which this right shall be exercised, property at once virtually ceases to be private, all private rights are overthrown, and we are in the high road to communism. ${ }^{\circ}$

While there were certainly other views about what was at stake in labor disputes like the Preston Strike, it is true that there was widespread disapproval of strikes. Many were concerned that hostile relations between the classes would jeopardize trade and, hence, the nation's prosperity. Some accused union leaders of creating class hostility in order to further their own self-interest. Others, like Dickens and Gaskell, declared their sympathy with the working classes and felt a moral responsibility to alleviate the negative side effects of industrial capitalism and to promote class harmony. While social legislation, philanthropic schemes, utopian experiments, and educational institutions for teaching political economy to the poor were promoted as possible solutions to the problem of uniting the classes, many people, including several of the lecturers discussed in the Edinburgh Review article, favored personal contacts between potentially hostile factions as the best way of reconciling what they saw as conflicting class interests. Some, like F. D. Maurice and his colleagues at the Working Men's College, attempted to form collegial

10 The Preston Strike: An Enquiry into Its Causes and Consequences (Manchester: George Simms, 1854), pp. 15-16. 